\title{
Isolation of Andrographolide from Andrographis lineata Wall. ex Nees var. lawii C.B. Clarke and its Anticancer Activity against Human Ovarian Teratocarcinoma
}

\author{
Medha A. Bhat, Hosakatte Niranjana Murthy*
}

Medha A. Bhat, Hosakatte Niranjana Murthy*

Department of Botany, Karnatak University, Dharwad 580003, INDIA.

\section{Correspondence}

Hosakatte Niranjana Murthy

Department of Botany, Karnatak University, Dharwad 580003, INDIA.

E-mail: hnmurthy60@gmail.com

History

- Submission Date: 09-01-2021;

- Review completed: 26-02-2021;

- Accepted Date: 05-03-2021.

DOI : 10.5530/pj.2021.13.84

Article Available online http://www.phcogj.com/v13/i3

Copyright

(C) 2021 Phcogj.Com. This is an openaccess article distributed under the terms of the Creative Commons Attribution 4.0 International license.

\begin{abstract}
Introduction: Andrographolide is a well-known anticancer phytochemical often isolated from Andrographis paniculata (Burm. f.) Nees. (Acanthaceae). Though Andrographis lineata Wall. ex Nees var. lawii C.B. Clarke (ALw) which also belongs to the same family has an adequate amount of andrographolide; remained untouched for isolation of andrographolide and anticancer studies. Therefore, this study was targeted to isolate the andrographolide from the leaves of ALW and to assess its role inthe induction of apoptosis against the human ovarian teratocarcinoma (PA-1) cell line. Methods: Column chromatography, thin-layer chromatography (TLC), preparative TLC were used for the isolation and purification while melting point, ultraviolet (UV)-visible spectroscopy, Fourier transform infrared (FTIR), proton nuclear magnetic resonance ( $\left.{ }^{1} \mathrm{H} \mathrm{NMR}\right)$, carbon-13 (C13) nuclear magnetic resonance $\left({ }^{13} \mathrm{C} N M R\right)$ analysis were carried out for characterization of the compound. 3-(4,5-dimethylthiaxo-2yl) 2, 5-diphenyl tetrazolium bromide (MTT) assay was carried out for cytotoxicity test and further Annexin-V staining, caspase 3 activity, B-cell lymphoma-2 (Bcl-2) activity, cell cycle analysis, and DNA damage study by terminal deoxynucleotidyl transferase (dUTP) nick end labeling (TUNEL) assays were carried out for apoptosis study. Results: Andrographolide was isolated from the methanolic extract of leaves of ALw which had a melting point of $230^{\circ} \mathrm{C}, \lambda_{\max }$ at $223 \mathrm{~nm}$. FTIR results proved the presence of hydroxyl group, alkanes, carbon-carbon double bond, and a characteristic gamma lactone carbonyl. NMR data confirmed the 20 carbon structure. In the MTT assay cytotoxicity against PA-1 was at $3.7 \mu \mathrm{g} / \mathrm{ml}$ with other apoptotic assays supporting the induction of apoptosis by the compound at that concentration. Conclusion: ALw is proved to be an alternate source of andrographolide with potential abilities to induce apoptosis in ovarian cancer cells.
\end{abstract}

Key words: Andrographis, Andrographolide, Anticancer activity, Apoptosis, Ovarian teratocarcinoma.

\section{INTRODUCTION}

Andrographolide, an ent-labdane diterpenoid compound that has been isolated from the stem and leaves of Andrographis paniculata (Burm.f.) Nees by Gorter. ${ }^{1}$ It is proved to exhibit significant biological activities including antioxidant, anti-inflammatory, antimicrobial, antiseptic, hypolipidemic, cytotoxic, hepatoprotective, neuroprotective activities. $^{2}$ Andrographolide is also accepted as a potent anticancer drug, studied extensively for the treatment of various kinds of cancers like brain, heart, lung, pancreas, prostate, oral, liver, colon, kidney, breast, skin, colorectal, blood, and bone marrow cancers. Mechanism of anticancer activity of andrographolide includes suppression of cyclins and cyclin-dependent kinases, induction of tumour suppressor proteins $\mathrm{p} 53$ and p21, increased level of Bax protein and decreased level of Bcl-2 proteins in a leukaemia cell line (HL-60 cells), G0/G1 phase arrest in breast cancer cell line (MCF-7 cells), cell cycle arrest in G2/M phase in human glioblastoma cell lines (glioblastoma U251 and U87), breast cancer, human leukaemia K562 cells. ${ }^{2}$
Cancer has become the major cause of mortality in recent years. Nearly about $50 \%$ of currently used anticancer drugs are from natural sources. ${ }^{3}$ Ovary cancer is the fifth common cause of death among women of the United States according to the study of the American Cancer Society. In India, the incidence of ovarian carcinoma is increasing over the years. ${ }^{4}$ Studies have shown the cytotoxic activity of leaf extract Pergularia daemia against human ovarian teratocarcinoma (PA-1 cells). ${ }^{5}$ Similarly studies have also shown that paclitaxel extracted from Taxus spp. inhibited the growth of PA- 1 cells to $50 \%$ at a concentration of $30 \mathrm{nM} .{ }^{6}$ However, PA- 1 cells showed resistance against curcumin and thus it could not induce any apoptosis in the cells. ${ }^{7}$ There is a lack of systematic work on the use of phytochemicals against PA- 1 cells.

To date, Andrographis paniculata (Acanthaceae) was being used as the only major source of andrographolide from which several researchers have isolated it using different techniques. Andrographis lineata Wall. ex Nees which belong to the same genus has potential medicinal values. It is being used as ethnobotanical medicine for skin diseases,

Cite this article: Bhat MA, Murthy HN. Isolation of Andrographolide from Andrographis lineata Wall. ex Nees var. lawii C.B. Clarke and its Anticancer Activity against Human Ovarian Teratocarcinoma. Pharmacog J. 2021;13(3): 660-8. 
fever, constipation, bronchitis. ${ }^{8}$ However, Andrographis lineata Wall. ex Nees var. lawii C.B. Clarke is an underexplored species, though it has a notable quantity of andrographolide. ${ }^{9}$ Given the above, the present study was carried out with the objective isolation, characterization of andrographolide from Andrographis lineata Wall. ex Nees var. lawii C.B. Clarke and to study the anticancer activity of andrographolide on the human ovarian teratocarcinoma cell line.

\section{MATERIALS AND METHODS}

\section{Extraction of phytochemicals}

Plants of Andrographis lineata Wall. ex Nees var.l awii C.B. Clarke were collected from Jogimatti, Chitradurga district, Karnataka $\left(14^{\circ} 09^{\prime} 31.9^{\prime \prime} \mathrm{N}\right.$ $\left.76^{\circ} 23^{\prime} 43.8^{\prime \prime} \mathrm{E}\right)$. The plants were maintained in the experimental garden and plants were identified using local flora and a voucher specimen (DSD-06A) was deposited at Herbarium, Shivaji University, Kolhapur (SUK), India. Leaves were collected from matured plants, washed thoroughly with distilled water, and then were dried to constant weight under shade and ground to powder. $30 \mathrm{~g}$ such powder was used for the extraction of phytochemicals with methanol (Analytical grade, HiMedia, Mumbai, India) using soxhlet apparatus at $70^{\circ} \mathrm{C}$ for $8 \mathrm{~h}$. The solvent is evaporated after extraction to obtain a green extract.

\section{Isolation of andrographolide}

Four $\mathrm{g}$ of the extract was dissolved in $10 \mathrm{ml}$ of methanol and loaded on analytical TLC (precoated sheets with silica, Merck, Mumbai, India) plates. Different solvent systems were tested for standardization viz. pure chloroform, ethyl acetate, ethanol, 9:1- chloroform: ethanol, 1:9 - chloroform: ethanol, 6:4- ethanol: ethyl acetate, 1:6:3- chloroform: methanol: ethyl acetate. Among the various solvents tested pure chloroform showed maximum bands. Methanol mixed with crude was evaporated and washed with chloroform to remove nonpolar and colored compounds. Crude left behind showed a brownish-red ring indicating the presence of terpenoids for the Salkowski test and a characteristic band for andrographolide.

The extract was saturated with $2 \mathrm{~g}$ of silica (mesh size 60-120, HiMedia, Mumbai, India) and subjected to column chromatography where the column conditions were: internal diameter of the column $-4.5 \mathrm{~cm}$; length of stationary phase $-20 \mathrm{~cm}$; length of sample bind gel load -1.5 $\mathrm{cm}$; mobile phase -chloroform: methanol: ethyl acetate (1:6:3). The first fraction obtained had shown the band in TLC similar to the band of standard andrographolide (Sigma- Aldrich, USA).

Column chromatography was followed by preparative TLC where $5 \mathrm{~g}$ of silica (mesh size 60-120, HiMedia, Mumbai, India) in $10 \mathrm{ml}$ of distilled water was coated on a glass TLC plate. Silica was activated by keeping it in a hot air oven overnight at $80^{\circ} \mathrm{C}$. The fraction with andrographolide was streaked along the side and let run in ethanol. Band obtained was dissolved in ethanol to separate andrographolide from silica. The supernatant was dried to get the crystals of andrographolide at room temperature.

\section{Spectral analysis}

Maximum absorption in the UV-visible region of the electromagnetic spectrum was determined. A solution of $1 \mathrm{mg} / \mathrm{ml}$ isolated andrographolide was prepared using methanol and scanned for the range of UV-visible spectrum $(190-1000 \mathrm{~nm})$ using a UV visible spectrophotometer (Jasco V 750, Japan). The melting point was determined using the melting point apparatus. FTIR analysis was done to determine the functional groups using IR transmission spectra. $5 \%$ of the sample was used to prepare the $\mathrm{KBr}$ disc and scanned at the wave length ranging from 400 to $4000 \mathrm{~cm}^{-1}$ (Thermo Fisher Scientific, Nicolet 6700, USA). ${ }^{1} \mathrm{H}$ NMR (399.8 MHz) and ${ }^{13} \mathrm{C} \mathrm{NMR}(100.53 \mathrm{MHz})$ analyses were done for further confirmation using deuterated DMSO (Jeol, Japan).

\section{Cell culture}

PA-1 (human ovarian teratocarcinoma; ATCC CRL-1572) cells were obtained from The National centre for cell science, Pune, India. Cells were revived and were maintained in Dulbecco's Modified Eagles Medium (DMEM, HiMedia, Mumbai, India) supplemented with $10 \%$ fetal bovine serum (FBS) with $37^{\circ} \mathrm{C}$ in a humidified incubator (95\% air and $5 \% \mathrm{CO}_{2}$ ).

\section{Cytotoxicity test}

Andrographolide isolated from ALw was tested for its in vitro cytotoxicity activity using the 3-(4,5-dimethylthiaxo-2yl) 2, 5-diphenyl tetrazolium bromide (MTT) assay. ${ }^{10}$ The cell lines were maintained at $37^{\circ} \mathrm{C}$ in a humidified incubator $\left(95 \%\right.$ air and $\left.5 \% \mathrm{CO}_{2}\right)$ and plated into 96 well microplates $(10,000$ cells $/ 200 \mu \mathrm{l})$. The isolate was dissolved in dimethyl sulphoxide (DMSO) and further diluted with Dulbecco's modified eagle medium with high glucose (DMEM HG) medium to obtain a wide range of concentrations viz. $10,20,40,80$, and $160 \mu \mathrm{g} /$ $\mathrm{ml}$. After $24 \mathrm{~h}$ of incubation, the test sample was added to the wells containing the cells and incubated for $24 \mathrm{~h} .200 \mu \mathrm{l}$ of MTT solution was added while the DMSO solution was used as a negative control. After 3 $\mathrm{h}$ of incubation, $100 \mu \mathrm{l}$ DMSO was used to dissolve formazan crystals formed. The optical density was measured at $570 \mathrm{~nm}$ using a microplate reader (Bio-Rad, model 3550, USA). Cell viability was calculated using the formula (mean optical density (OD) of test sample/ mean OD of untreated cells) x 100. IC $_{50}$ was generated from the dose-response curve.

\section{Detection of apoptosis by FITC annexin V assay}

Fluorescein isothiocyanate Annexin-V (FITC Annexin V) staining was done by the flow cytometric method. ${ }^{11}$ PA-1 cells were seeded on a 6-well plate at a density of $3 \times 10^{5}$ cells/ $2 \mathrm{ml}$ and incubated in a $\mathrm{CO}_{2}$ incubator at $37^{\circ} \mathrm{C}$. Cells were washed with $1 \mathrm{x}$ phosphate-buffered saline (PBS) to remove the traces of medium after the incubation of 24 hours. Cells were treated with an $\mathrm{IC}_{50}$ value of isolated andrographolide (3.7 $\mu \mathrm{g} / \mathrm{ml}$ ) which was prepared in $2 \mathrm{ml}$ of culture medium. Trypsinized cells were harvested by centrifugation at $300 \mathrm{x} g$ at $25^{\circ} \mathrm{C}$ for further use. PBS washed cells were then treated with $1 \mathrm{x}$ binding buffer. Primary staining was done by adding $5 \mu \mathrm{l}$ of FITCAnnexin V. After addition, gentle mixing was done and incubated at room temperature for $15 \mathrm{~m}$ in dark. Secondary staining was done with $5 \mu$ of propidium iodide (PI) along with $400 \mu \mathrm{l}$ of $1 \mathrm{x}$ binding buffer. Flow cytometric (Cytomics FC 500, Beckman Coulter, USA) analysis was carried out immediately using FL1 (525 nm bandpass filter) detector for FITC Annexin V fluorescence and FL3 (620 nm bandpass filter) detector for PI fluorescence.

\section{Caspase 3 activity by flowcytometry ${ }^{12}$}

Human ovarian teratocarcinoma cell cultures were treated with 3.7 $\mu \mathrm{g} / \mathrm{ml}$ of isolated andrographolide and then harvested after 24 hours at $37^{\circ} \mathrm{C}$ incubation. $0.5 \mathrm{ml} 2 \%$ paraformaldehyde (PFA) solution was used to fix the cells followed by $20 \mathrm{~m}$ of incubation to facilitate further immune fluorescent staining. Cell lyses were done by the $0.1 \%$ triton-x 100 detergent treatment. After washing with $0.5 \%$ bovine serum albumin (BSA), $20 \mu \mathrm{l}$ FITC rabbit anti-active caspase-3 IgG antibodies were added and incubated in dark for $30 \mathrm{~m}$. Unbound antibodies were removed by washing with $1 \mathrm{x}$ PBS. Green fluorescence was measured in the FL1 detector using a $525 \mathrm{~nm}$ band pass filter.

\section{Determination of $\mathrm{Bcl}-2$ activity by flow cytometry}

PA-1 cells were treated with $3.7 \mu \mathrm{g} / \mathrm{ml}$ of isolated andrographolide then harvested after the incubation as explained previously. Fixation of the cells before the immunofluorescent staining was done by adding $0.5 \mathrm{ml}$ 
$2 \%$ paraformaldehyde (PFA) solution followed by $20 \mathrm{~m}$ of incubation. After washing with $0.5 \%$ bovine serum albumin (BSA) in $1 \mathrm{x}$ phosphatebuffered saline (PBS), $0.1 \%$ of triton-x 100 (prepared in $0.5 \%$ BSA) was added and incubated for $10 \mathrm{~m}$ to remove the traces of triton-x 100 cells are washed with $0.5 \%$ bovine serum albumin (BSA) in $1 \mathrm{x}$ PBS 2 times. Along with $0.5 \% \mathrm{BSA}, 20 \mu \mathrm{lPE}$ mouse anti-human Bcl-2 antibodies were added, mixed well, and incubated for $30 \mathrm{~m}$ in dark at room temperature. After washing off the excess antibodies with $1 \mathrm{x}$ PBS, Bcl2 activity was measured by measuring orange fluorescence in the FL2 detector using a $575 \mathrm{~nm}$ bandpass filter.

\section{Cell cycle analysis by flowcytometry ${ }^{13}$}

PA-1 cells pretreated with $3.7 \mu \mathrm{g} / \mathrm{ml}$ of andrographolide for $16 \mathrm{~h}$ were harvested and washed with $1 \mathrm{x}$ PBS. Fixation was done using chilled $70 \%$ ethanol $\left(-20^{\circ} \mathrm{C}\right)$ and $400 \mu \mathrm{l}$ of PI-RNase solution was added to evaluate the DNA content. PI fluorescence was collected in an FL3 detector using a $620 \mathrm{~nm}$ bandpass filter.

\section{Detection of DNA damage by TUNEL assay ${ }^{14}$}

Andrographolide $(3.7 \mu \mathrm{g} / \mathrm{ml})$ treated cells were harvested, fixed with chilled $70 \%$ ethanol $\left(-20^{\circ} \mathrm{C}\right)$ and were suspended in $50 \mu \mathrm{l}$ of DNA labeling solution (reaction buffer+ terminal deoxynucleotidyl transferase (tdt) enzyme + FITC deoxy-uridinetriphosphate (dUTP)
+ distilled water). After incubating it for $60 \mathrm{~m}$ at $37^{\circ} \mathrm{C}, 1 \mathrm{ml}$ of rinse buffer ( $0.05 \%$ sodium azide) was added and centrifuged at $300 \mathrm{x} g$ for 5 minutes; repeat the same for one more time, and the supernatant was removed. $0.5 \mathrm{ml}$ of PI-RNase was added and incubated for $30 \mathrm{~m}$ in dark at room temperature. The extent of DNA damage caused by andrographolide was analyzed by analyzing FITC (green) fluorescence in the FL1 detector using a $525 \mathrm{~nm}$ band pass filter.

\section{RESULTS AND DISCUSSION}

\section{Spectral analysis of isolated andrographolide}

Andrographolide which was isolated from ALw had a melting point of $230^{\circ} \mathrm{C}$. Further, andrographolide was scanned for its absorbance in the range of $190-1000 \mathrm{~nm}$ it was found that at $223 \mathrm{~nm}$ it showed maximum absorption (Figure 1), these results were comparable to standard andrographolide (Sigma-Aldrich) and were similar to the earlier reported results. ${ }^{15-17}$. FTIR results of andrographolide isolated from ALw showed bond stretching at 3398 (hydroxyl group), 3099 to 2849 (alkanes), 1674, and 1647 (carbon-carbon double bond). A characteristic stretch of andrographolide corresponding to gamma lactone carbonyl stretching could be observed at $1727 \mathrm{~cm}^{-1}$ (Figure 2A). The above data were comparable to standard andrographolide (Figure 2B) as well as earlier reported results ${ }^{18}$. ${ }^{1} \mathrm{H}$ NMR (DMSO-d6, 399.87 MHz) was found

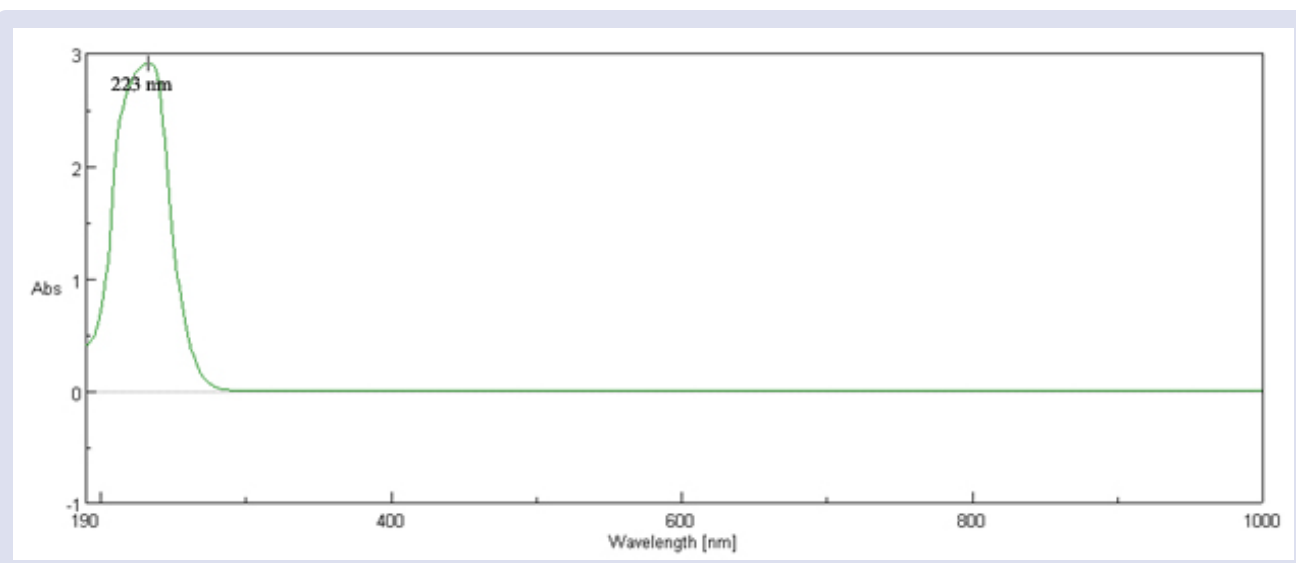

Figure 1: The UV-visible spectrum of isolated compound.

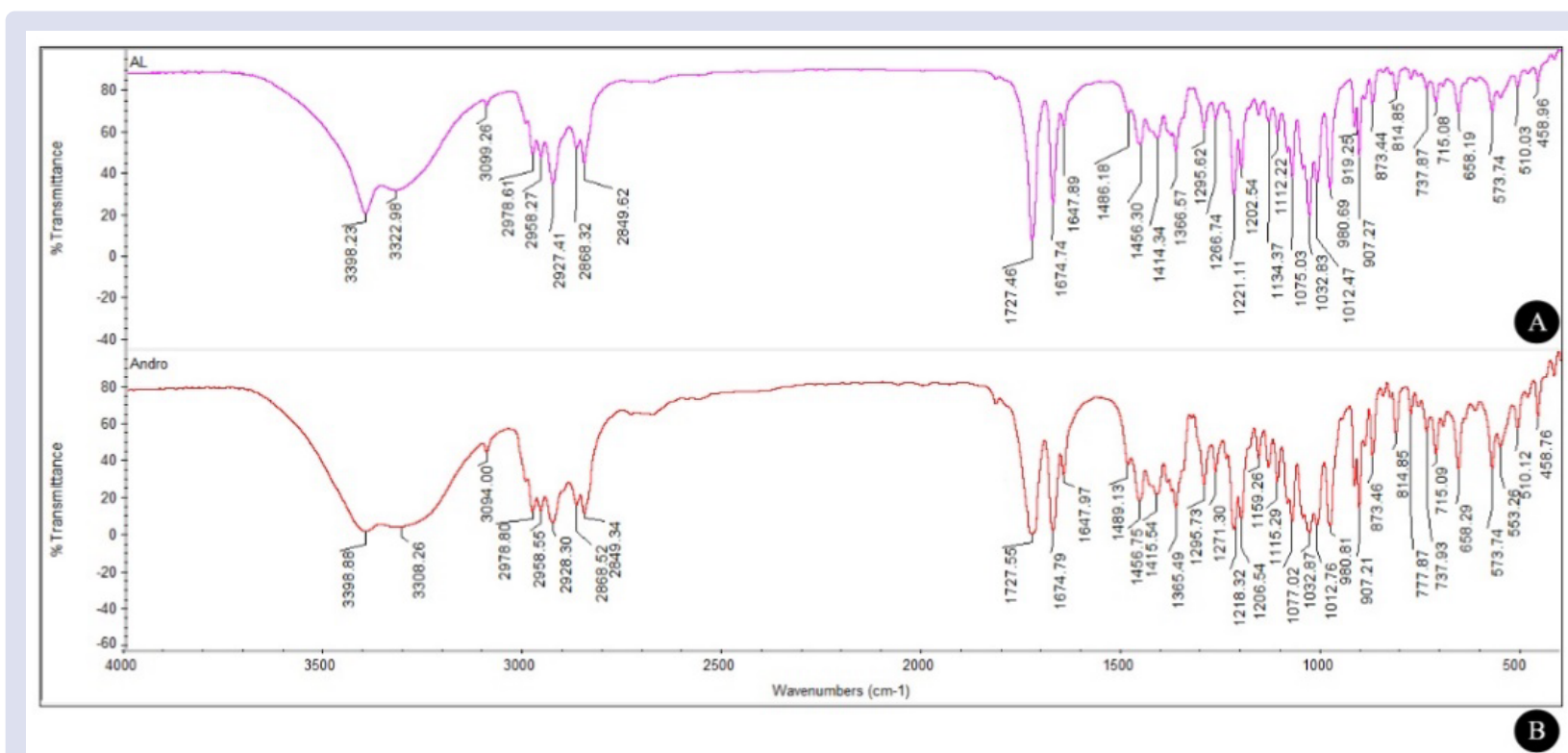

Figure 2: FTIR transmittance spectrum at 400-4000/cm of isolated compound (A) standard andrographolide (B). 
to be $\delta$ ppm $6.59(1 \mathrm{H}), 5.70(1 \mathrm{H}), 5.05(1 \mathrm{H}), 4.82(2 \mathrm{H}), 4.59(1 \mathrm{H}), 4.34$ $(1 \mathrm{H}), 4.04(2 \mathrm{H}), 3.79(1 \mathrm{H}), 3.20(2 \mathrm{H}), 2.26(1 \mathrm{H}), 1.79(6 \mathrm{H}), 1.31(1 \mathrm{H})$, $1.18(2 \mathrm{H}), 1.04(3 \mathrm{H}), 0.62(3 \mathrm{H})$ and also a characteristic gamma lactone chiral carbon proton attached to $-\mathrm{OH}$ group had resonated at 6.579 ppm as triplet of doublet (Figure 3A). ${ }^{13} \mathrm{C}-\mathrm{NMR}$ (101 MHz, DMSOd6): $\delta$ ppm 170.49, 148.12, 146.84, 129.50, 108.80, 78.95, 74.87, 74.79, $65.03,63.16,56.00,54.88,42.80,39.11,38.03,37.02,28.41,24.48,23.61$,
15.27. ${ }^{13} \mathrm{C}$-NMR data presented of andrographolide isolated from ALw were correlating with earlier reports. ${ }^{15}$

\section{Cytotoxicity test}

Cell metabolic activity can be measured colorimetrically by MTT assay. NADPH-dependent cellular oxidoreductase enzymes can reduce the tetrazolium dye MTT to insoluble formazan crystals which is purple.

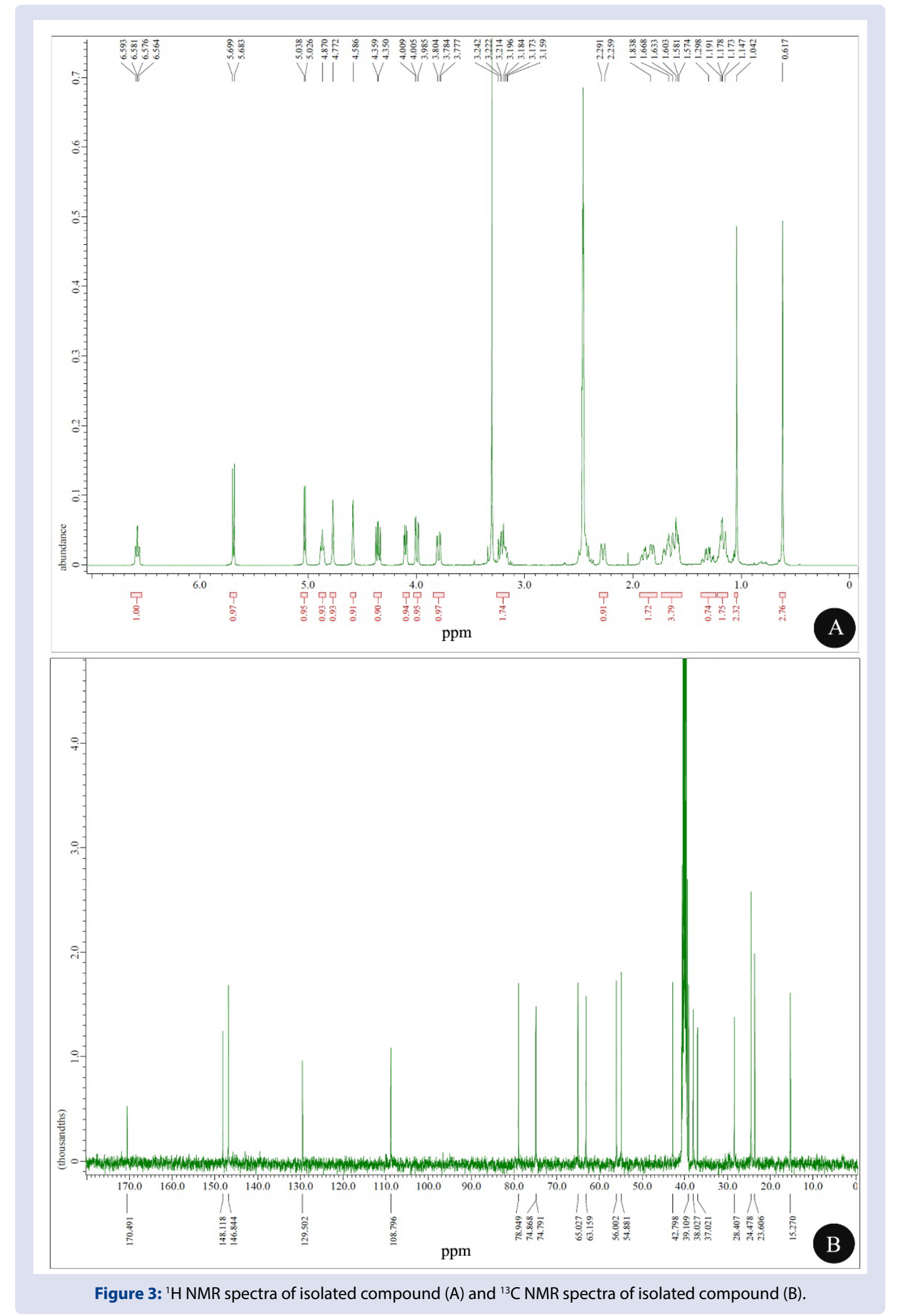




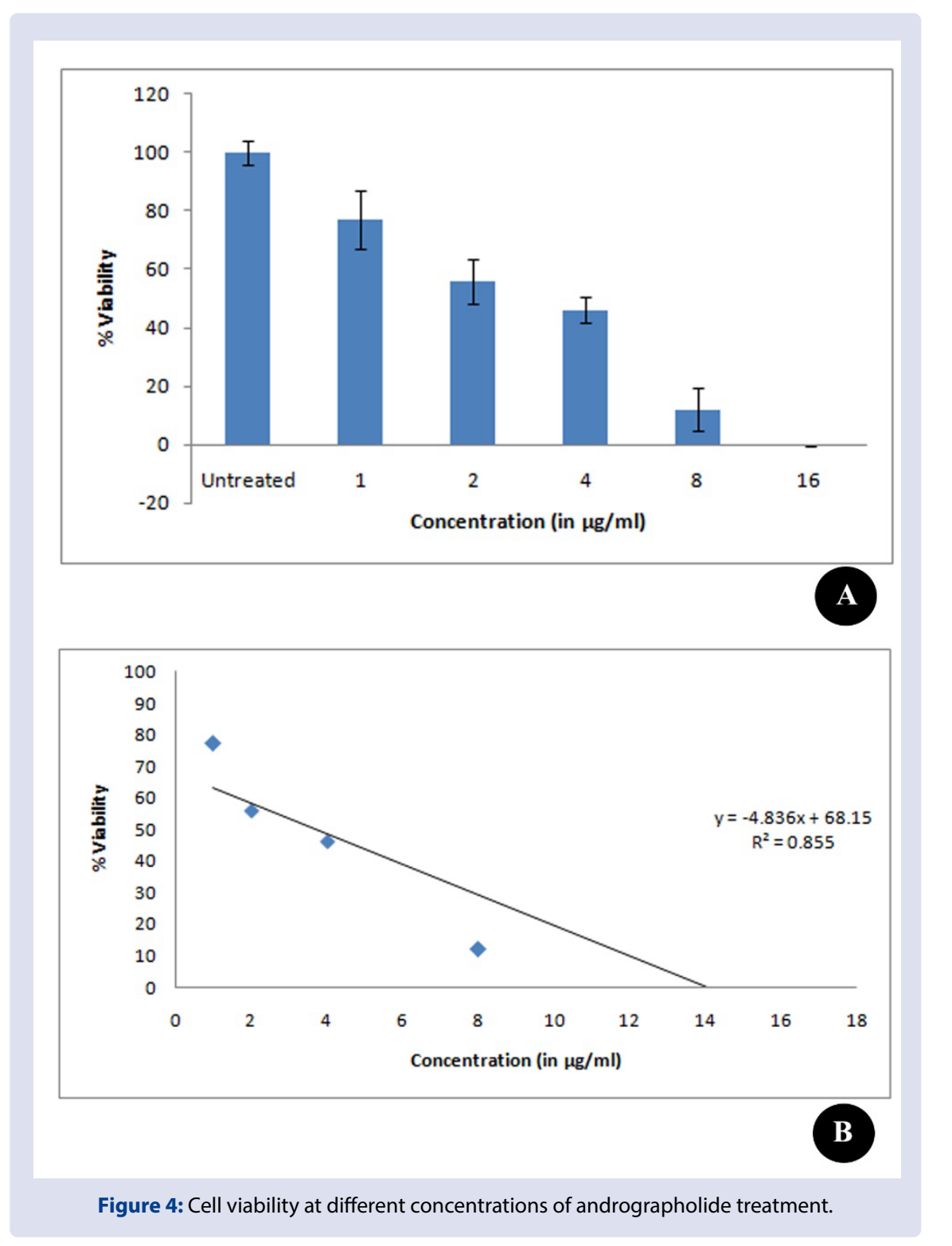

Thus, the intensity of the colour measures the cell viability in terms of enzymatic conversion of MTT into formazan. $\mathrm{IC}_{50}$ value calculated by the dose-response curve was found to be $3.7 \mu \mathrm{g} / \mathrm{ml}$ (Figure 4). Such a lower $\mathrm{IC}_{50}$ value proved the good cytotoxicity of andrographolide against human ovarian teratocarcinoma cells.

\section{Detection of apoptosis by FITC Annexin V assay}

Differential staining with annexin $\mathrm{V}$ fluorescein isothiocyanate and propidium iodide showed that the cells were shifted to the second quadrant representing early apoptosis (from $6.25 \%$ to $21.8 \%$ ) (Figure $5 \mathrm{~A}$ and $5 \mathrm{~B}$ ) in the andrographolide treated cells when compared to untreated cells indicating that andrographolide is inducing the apoptosis in PA-1 cells.

\section{Caspase 3 activity by flowcytometry}

Cysteinyl aspartate proteinases 3 (Caspase 3) are effecter caspases that execute apoptosis. These are the important caspases that can be activated by both intrinsic and extrinsic pathways responsible for the cleavage of multiple regulatory and structural proteins that are necessary for the survival of the cell. ${ }^{19}$ Flowcytometric estimation of caspase 3 using FITC rabbit anti-active caspase-3 IgG antibodies had shownan increased number of cells with activated caspase 3 after the andrographolide treatment (15\%; Figure 5D) when compared to control (8.4\%) (Figure 5C). Increased caspase 3 positive cells indicated an increased level of apoptosis.

\section{Determination of $\mathrm{Bcl}-2$ activity by flowcytometry}

Bcl-2 are anti-apoptotic proteins that protect the cells from apoptosis ${ }^{20}$. Estimation of $\mathrm{Bcl}-2$ activity by $\mathrm{PE}$ mouse anti-human $\mathrm{Bcl}-2$ antibodies had shown a considerable increase in the number of cells with a low level of Bcl-2 (16.9\%, Figure 5F) when compared to untreated cells (4.19\%, Figure 5E).

\section{Cell cycle analysis by flowcytometry}

The results of cell cycle studies reveal that a higher level of cells was existing at the G2/M phase with the andrographolide treatment (55.6\%, Figure $5 \mathrm{H})$ when compared to control $(33.7 \%$, Figure $5 \mathrm{G})$, this evidence suggests that cell cycle arrest occurs at G2/M phase. Similar to the present studies Liu and $\mathrm{Chu}^{21}$ have reported that andrographolide was arresting the human melanoma cells at the G2/M phase. Sub G1 cells had increased from 1.21 to $5.42 \%$ indicating DNA damage after the treatment of andrographolide. 

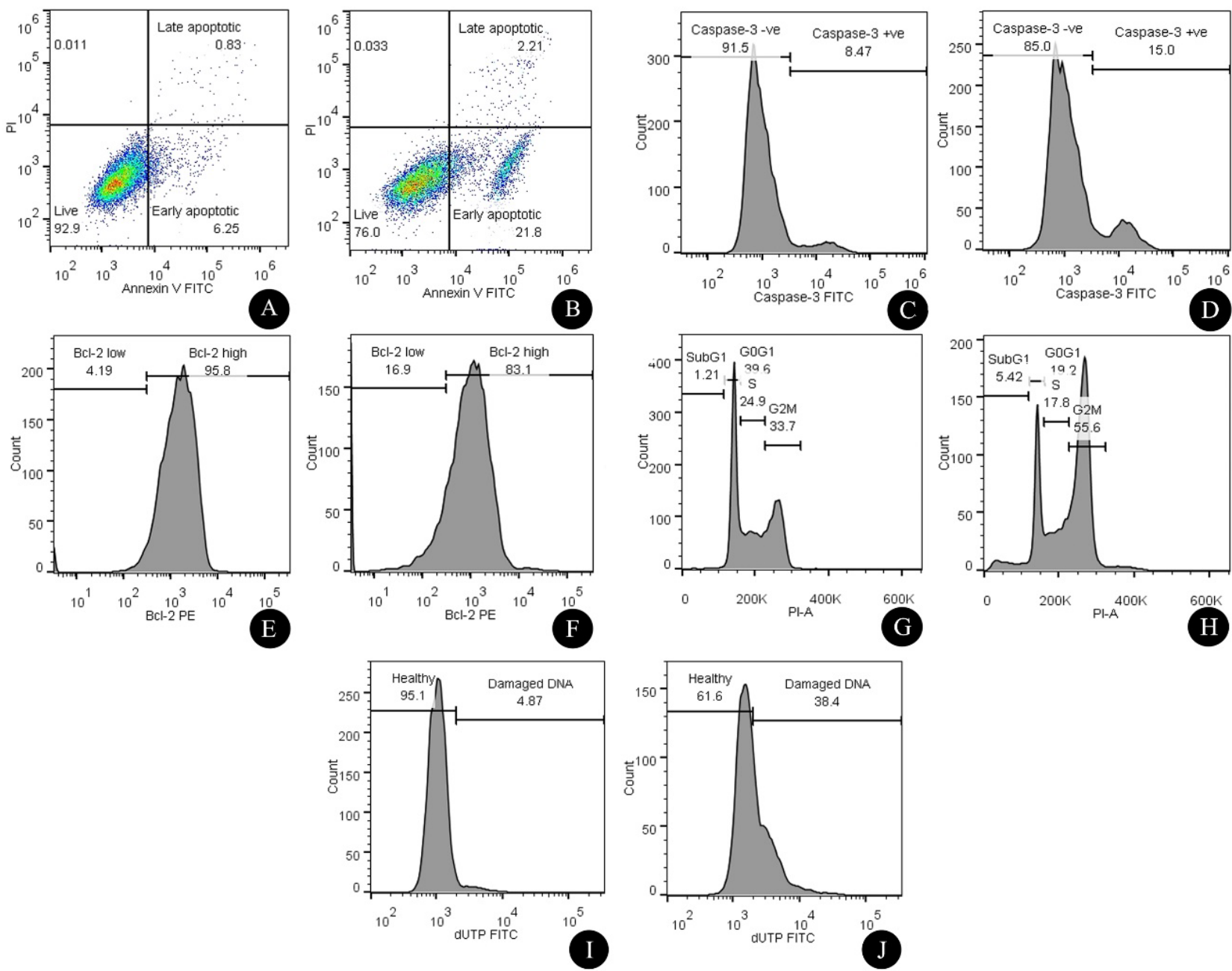

Figure 5: Flow cytometry analysis of andrographolide induced apoptosis in PA1 cells, Annexin V FITC staining of untreated cells (A) and treated PA cells (B); caspase-3 activity in untreated cells (C) and treated PA1 cells (D); Bcl-2 activity of untreated cells (E) and treated PA1 cell (F); cell cycle analysis of untreated cells $(\mathrm{G})$ and treated PA1 cells (H); TUNEL assay showing damaged DNA of untreated cells (I) and treated PA1 cells $(\mathrm{J})$.

\section{Detection of DNA damage by TUNEL assay}

The extent of DNA fragmentation was determined by terminal deoxynucleotidyl transferase end labeling (TUNEL) assay. In untreated cells, $95.1 \%$ cells were healthy (Figure 5I), whereas, in treated cells, damaged cells were increased to $38.4 \%$ and there was a decline in the healthy cells to $61.6 \%$ (Figure $5 \mathrm{~J}$ ).

\section{CONCLUSION}

The results obtained at the end of the study conveyed that Andrographis lineata Wall. ex Nees var. lawii C.B. Clarke can be used as an alternative source for andrographolide. The andrographolide thus isolated was a potent anticancer agent against ovarian teratocarcinoma leading to further studies in this regard.

\section{REFERENCES}

1. Gorter K. The bitter constituent of Andrographis paniculata Nees. Ree Trav Chim. 1911;30:150-60.

2. Islam MT, Ali ES, Uddin SJ, Islam MA, Shaw S, et al. Andrographolide, a diterpene lactone from Andrographis paniculata and its therapeutic promises in cancer. Cancer Lett. 2018;420:129-45.
3. Das B, Chowdhury C, Kumar D, Sen R, Roy R, et al. Synthesis, cytotoxicity and structure-activity relationship (SAR) studies of andrographolide analogs as an anti-cancer agent. Bioorg Med Chem Lett. 2010;20:6947-50

4. Shabir S, Gill PK. The global scenario on ovarian cancer - Its dynamics, relative survival, treatment, and epidemiology. Adesh Univ J Med Sci Res 2020;2:17-25.

5. Martin S, Kavitha PD, Rathi MA, Kumar DG, Gopalakrishnan VK Cytotoxic activity of Pergularia daemia against ovarian cancer cell lines OAW-42 and PA-1. J Nat Pharm. 2011;2(4): 203-9.

6. Kim S, Juhnn Y, Song Y. Akt involvement in Paclitaxel Chemoresistance of Human Ovarian Cancer Cells. Ann NY Acad Sci. 2007;1095:82-9.

7. Khar A, Ali AM, Pardhasaradhi BVV, Varalakshmi C, Anjum R, Kumari $\mathrm{AL}$. Induction of stress response renders human tumour cell lines resistant to curcumin- mediated apoptosis: role of reactive oxygen intermediates. Cell Stress and Chaperones. 2001;6(4):368-76.

8. Alagesaboopathi C. Phytochemical analysis and antimicrobial evaluation of Andrographis lineata Nees leaves and stem extracts. Afr J Pharmacy Pharmacol. 2011;5(9):1190-95.

9. Dalawai D, Aware C, Jadhav JP, Murthy HN. RP-HPLC analysis of diterpene lactones in leaves and stems of different species of Andrographis. Nat Prod Res. 2019;1-4.

10. Gerlier D, Thomasset N. Use of MTT colorimetric assay to measure cell activation. J Immunol Methods. 1986:94:57-63. 
11. Koopman G, Reutelingsperger CPM, Kuijten GAM, Keehnen RMJ, Pals ST, et al. Annexin $V$ for flow cytometric detection of phosphatidylserine expression on B cells undergoing apoptosis. Blood. 1994;84(5):1415-20.

12. Dai C, Krantz SB. Interferon-gamma induces upregulation and activation of caspases 1,3 , and 8 to produce apoptosis in human erythroid progenitor cells. Blood. 1999;93:3309-16.

13. Pozarowski P, Darzynkiewicz Z. Analysis of cell cycle by flow cytometry. Methods Mol Biol. 2004;281:301-11.

14. Walker PR, Kokileva L, LeBlanc J, Sikorska M. Detection of the initial stages of DNA fragmentation in apoptosis. BioTechniques. 1993;15:1032-40.

15. Matsuda T, Kuroyanagi M, Sugiyama S, Umehara K, Ueno A, Nishi K. Cell differentiation-inducing diterpenes from Andrographis paniculata Nees. Chem Pharm Bull. 1994;42:1216-25.

16. Sajeeb BK, Kumar U, Halder S, Bachar SC. Identification and quantification of andrographolide from Andrographis paniculata (Burn f.) Wall. Ex Nees. by RP-HPLC method and standardization of its market preparations. Dhaka Univ J Pharm Sci. 2015;14:71-8.
17. Sani YN, Haque M, Suryati K, Mohd KW, Khan A. Isolation and characterization of Andrographolide from Andrographis paniculata (Burm. F) Wall. Ex Nees and its total flavonoid effects from Kemaman, Malaysia. Int J Pharm QualAssur.2017;8(3):119- 24.

18. Gupta S, Choudhry MA, Yadava JNS, Srivastava V, Tandon JS Antidiarrhoeal activity of diterpenes of Andrographis paniculata (KalMegh) against Escherichia coli enterotoxin in vivo models. Int J Crude Drug Res.1990;28(4):273-83.

19. Degterev A, Boyce M, Yuan J. A decade of caspases. Oncogene. 2003;22:8543-67.

20. Hockenbery D, Nunez G, Milliman C, Schreiber RD, Korsmeyer $\mathrm{SJ} . \mathrm{Bcl}-2$ is an inner mitochondrial membrane protein that blocks programmed cell death. Nature. 1990;348:334-6.

21. Liu G, Chu H. Andrographolide inhibits proliferation and induces cell cycle arrest and apoptosis in human melanoma cells. Oncol Lett. 2018;15:5301-5. 


\section{GRAPHICAL ABSTRACT}

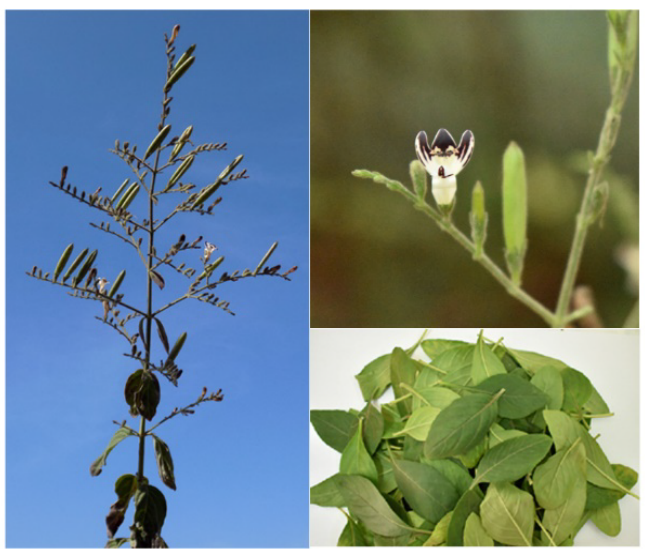

Andrographis lineata Wall. ex Nees var. lawii C.B. Clarke leaves dried and powdered

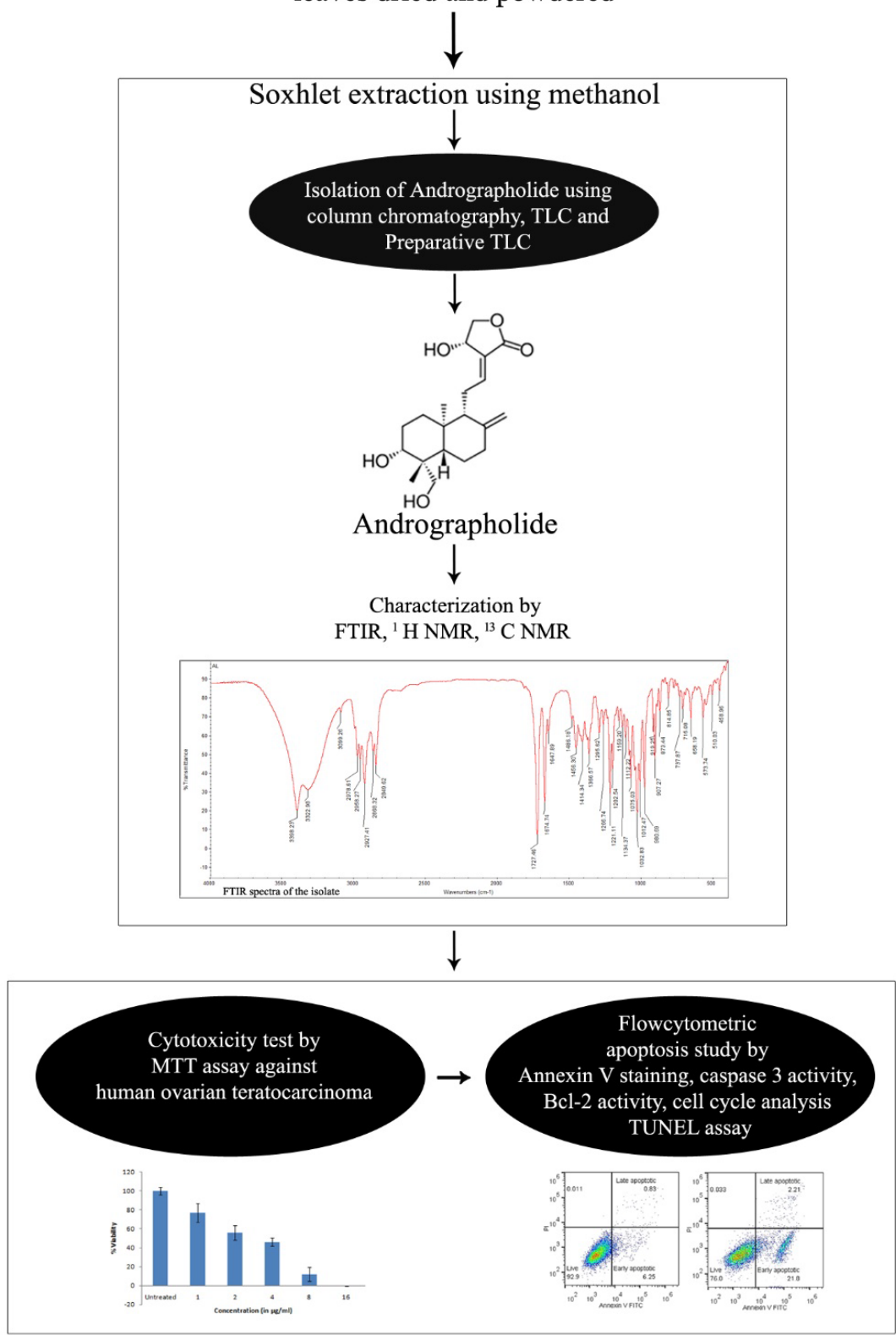




\section{ABOUT AUTHORS}

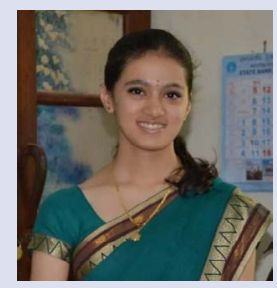

Medha A. Bhat is research scholar at Department of Botany, Karnatak University, Dharwad, India. She has completed Master of Science in Botany from same university.

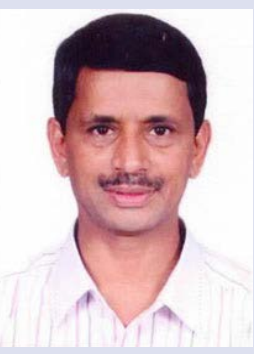

Hosakatte Niranjana Murthy professor in Department of Botany, Karnatak University, Dharwad, India, has obtained Ph.D. degree from the same university. He has tremendous passion for research and academics. Since 1986, Apart from his teaching experience of 34 years, he possesses extensive research experience in the area of plant biotechnology. Prof. Murthy has post-doctoral and collaborative research experience in many foreign research institutes. He has successfully completed more than 15 research projects funded by various agencies and guided several Ph.D. students. Prof. Murthy has published more than 200 research articles in international peer reviewed journals with high impact factor.

Cite this article: Bhat MA, Murthy HN. Isolation of Andrographolide from Andrographis lineata Wall. ex Nees var. lawii C.B. Clarke and its Anticancer Activity against Human Ovarian Teratocarcinoma. Pharmacog J. 2021;13(3): 660-8. 